\title{
Recuperating Rebellion Rewriting Revolting Women in(to) Nineteenth-Century Cuba and the Philippines
}

\author{
Kristina A. Escondo \\ Otterbein University, Ohio
}

\section{Abstract}

Using the late nineteenth-century independence movements as points of departure, this article uses a transoceanic approach to explore women's revolutionary history in Cuba and the Philippines. Using María Lugones' model of the modern/colonial gender system as a frame, I trace how women's revolutionary contributions became co-opted by male revolutionary figures in service to their own aims, rewriting the "revolting women" (in the rebellious sense) so that they were less "revolting" (viz. causing disgust) to nationalizing discourses. I argue that these national heroes, such as José Martí in Cuba and José Rizal in the Philippines, contributed to the minimization and even erasure of women's revolutionary participation and knowledge production through these rewritings. This allowed the coloniality of power to endure well into the new world order via reframing of a woman's place-or lack thereof-in the nationalizing project. To unearth the complexities of this minimized history, I dig deeper into these canonical literatures to find women's voices in letters, speeches, and oral histories to show how women sympathetic to the revolution actively conceptualized nation and citizenship through writing, protest, and action. As the field of Philippine-Hispanic Studies expands, this article aims to begin a conversation where we may confront and re-evaluate the privilege assigned to male national heroes' discourses in both Hispanic regions and the Philippines, 
especially when thinking nation. By doing so, women's rebellion may be recuperated and rewritten back into national narratives with the hope of triggering the decolonization of our own ways of thinking-nation and otherwise.

\section{Keywords}

Cuba, Philippines, revolution, women, mambisas, Malolos, nation, anti-colonialism, citizenship, coloniality of power, gender 


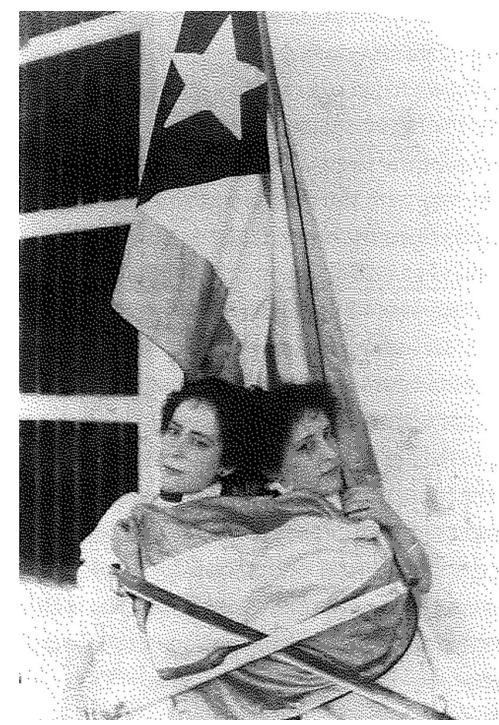

Fig. 1. Mambisas con bandera: Two Mambisas with a rebel flag (from Mambisas, Teresa Prados-Torreira, pg. 108)

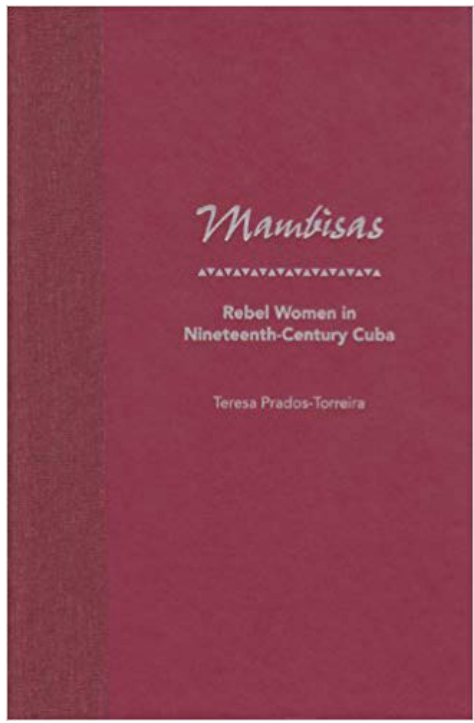

Fig. 2. Cover of Mambisas: Rebel Women of NineteenthCentury Cuba. Teresa Prados-Torreira (2005) 


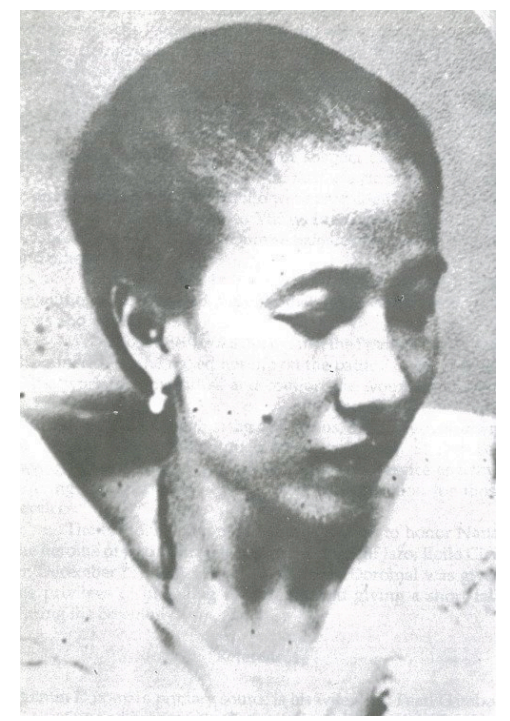

Fig. 3. Photo of Gregoria de Jesús, president of the women's chapter of the Katipunan

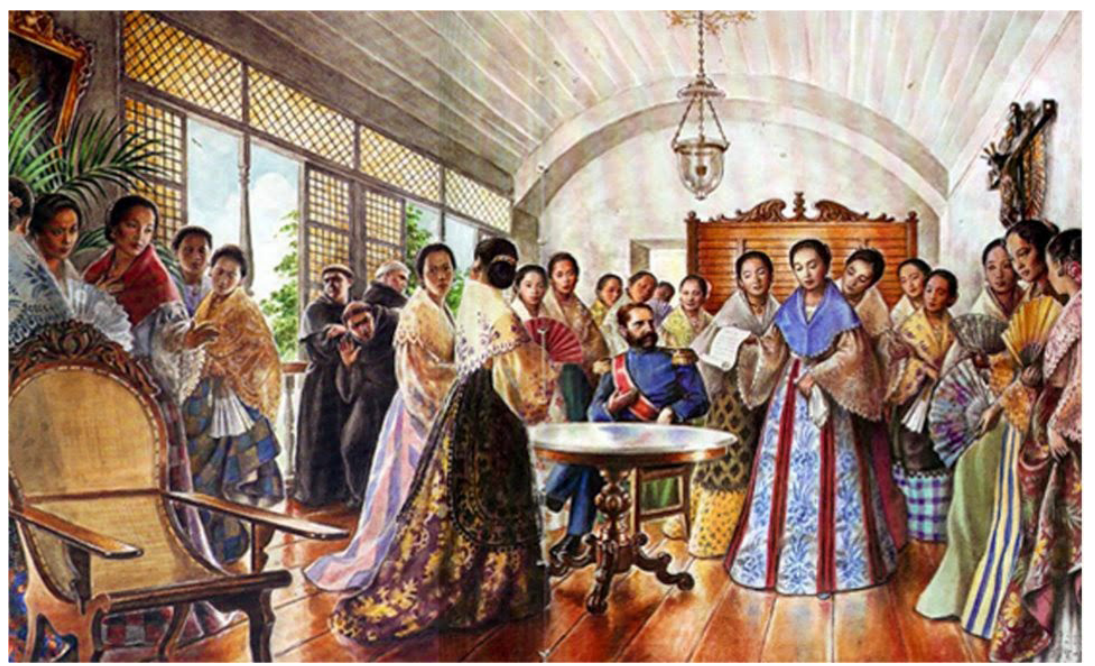

Fig. 4. Varleriano Weyler meeting with the Women of Malolos, painting by Rafael del Casal, used on the cover of Nicanor Tiongson's book of the same name 
In 1869, at the beginning of the Ten Years' War in Cuba, rebels gathered in Guáimaro for the First Constitutional Assembly of the Cuban Republic. At this assembly, patriot Ana Betancourt de Mora requested that the leaders of the rebellion recognize women's contributions to independence efforts in their vision for independence. She argued that, while the insurrection aimed to break the chains of colonization brought upon Cuba, women had made the same sacrifices as men and should also be full citizens. Betancourt was not only referencing women's participation at home or in the plaza-alongside the men, mambisas, or the women of the revolutionary mambi army, worked as messengers and undercover agents, organized fund-raising activities to buy weapons, and rose through military ranks as they fought for a free Cuba.

Across the world in the Philippines of 1888, a group of twenty young women of Malolos, Bulacán wrote, signed, and personally delivered a letter to Governor-General Valeriano Weyler to open a night school where they could learn the Spanish language. They had already been secretly learning the language but wanted their education to be legal. This plan was deliberately concealed from the friar curate of the town who had opposed these women's efforts, claiming that it would pose a threat to the government. After months of lobbying, the school was approved in February of 1889. Some of the women in this group later became connected to or directly involved with the Katipunan, ${ }^{1}$ the Filipino revolutionary organization that led the attack against Spanish forces in 1896, sparking the Philippine Revolution. Like the mambisas, the katipuneras sustained the revolution as fundraisers, strategists, nurses, soldiers, and spies.

In both Cuba and the Philippines, the concurrent independence movements of 1896 were the culmination of revolts and resistance against three centuries of Spanish colonization and oppression. Women in both archipelagos took an active stand in the home, the plaza, the courts, and on the battlefield alongside men as part of the anti-colonial movements against Spain and as part of the project of nation-building. In 1898, Spain lost its final colonies to the United States, triggering a new imperial presence on the island nations-and women have not stopped fighting. 
Drawing on the historical contexts of the late nineteenth-century independence movements, this article explores why women's revolutionary and literary histories in Cuba and the Philippines remain obscured. National formation in both archipelagos is inextricably linked to the legacies of both Spanish and American imperialism and provides a meaningful ground for this comparison. Using María Lugones' model of the modern/colonial gender system as a frame, I show how conventional views of women's revolutionary participation resulted from male nationalist literary production. In their creation of nationalizing discourses, male revolutionary writers intentionally recast women's work in service to (male) nationalists' own aims; in other words, they rewrote the "revolting women" (in the rebellious sense) so that they were less "revolting" (viz. causing disgust). I contend that national heroes-such as José Martí in Cuba and José Rizal in the Philippinescontributed to the minimization and even erasure of women's revolutionary participation and knowledge production through these rewritings.

Accordingly, these canonic versions show an incomplete picture of women's agency. To be clear, men's participation in civic and militant spheres undoubtedly outweighed women's participation due to the sociocultural constraints of the time; I do not claim otherwise. However, I do dispute her participation as only subordinate, minimal, or non-present. Women sympathetic to the revolution conceptualized nation and citizenship through writing, protest, and action. They established both anticolonialism and anticoloniality as their causes, expressing a comprehensive version of independence that included their own liberation from patriarchal gender restraints. In contrast, male revolutionaries' colonial mindset, underpinning their own understanding and assumptions underlying binary gender roles, aimed to preserve the patriarchal gender hierarchy. I claim that, once national heroes began to rewrite women, they softened the edges of the female claim to nation and independence by intercepting and refashioning women's discourse into one that maintained men's superiority. In my view, this played a role in allowing the coloniality of power to endure well into the new world order-precisely via their reframing of a woman's place, or lack thereof-in the nationalizing project. 


\section{Recuperating rebellion}

Scholars who analyze the relationships between women, nationalism, and revolution have consistently lamented mainstream history's overemphasis on women's revolutionary participation as either non-existent or limited to support roles. Correspondingly, in the construction of national mythologies, female representation tends to fall into three main archetypes: mother, traitor, or sex object (either as a sexual conquest or as a victim of rape). Often, these roles only serve to maintain a patriarchal vision of revolution, elevating men as the protagonists and relegating women as sidekicks, victims, or simply not present. While support roles certainly should not be minimized, women's civic and military contributions unmistakably attest to women's agency across all facets of revolution and merit attention. By recognizing how women have indeed been significant participants in nationalist movements and revolutions, we can then examine how and why their contributions to political and combat arenas have been grossly downplayed in masculine national sagas and rewrite them back into these narratives.

To this end, I look to scholars who have studied women's participation in the public arena. Because there are substantially more records from and about revolutionary women of Cuba, I begin here to better frame a comparative understanding of women's contributions in the Philippines. Notably, Lynn Stoner's article, "Militant Heroines and the Consecration of the Patriarchal Nation State" (2003), ${ }^{2}$ analyzes the nature of female combatant iconography that followed the Cuban wars of independence, the Early Republic, and the Cuban Revolution to see the role it plays for nation-building purposes in each era. I find useful her claim that women's heroism has been used to exalt male leaders of the revolution to maintain the power of a patriarchal state. Expanding upon Stoner's work, Teresa Prados-Torreira's Mambisas: Rebel Women in Nineteenth-Century Cuba (2005) provides a solid historico-cultural background and a comprehensive analysis of how women shaped the Wars of Independence and established the foundations for Cuban feminist activism in the twentieth century. Supporting my contention that women were, in fact, involved in nation-building projects, both scholars provide an inclusive 
look at the varied types of women's participation in Cuba's domestic, legal, and military spheres.

Likewise, in studying the Philippines, Christine Doran's "Literary Representations of Filipino Women in Revolution" (1998) analyzes how, despite women's important contributions to the Philippine Revolution, their literary representation has been marginal, symbolic, and passive, consistent with patriarchal stereotypes that then constitute women's subordination (205). This article corroborates my argument that national narratives have contributed to their minimization and continue to do so. Her related research that summarizes major conclusions across feminist studies connecting women, nationalism, and revolution also aids in showing how women's contributions are downplayed in national narratives. ${ }^{3}$ Complementing Doran's work, Nicanor Tiongson's extensive book The Women of Malolos (2004) explores the titular figures' active role in pursuing educational, social, and political reform in the time preceding the revolution. Because of the women's ties to the Katipunan, the founding of the Red Cross in Malolos, and their creation of the club Asociación Feminista de Filipinas, I use his text to bolster my claim that their action was rewritten for aims outside of their own. Read together, these texts provide a broad understanding of women's activity in revolutionary Philippines.

In my view, these works clearly attest to women's revolutionary involvement in both nations. When these images are juxtaposed with the literary production of male national heroes, the task of confronting and re-evaluating the privilege assigned to their discourses becomes stark-especially in Hispanic and Philippine Studies and especially when thinking nation. To be clear, the objective is not to create a new "archetypal national hero" by simply replacing historical male figures with their "exceptional female" version (nor should it be implied that women are the only group whose history has been suppressed). Rather, we must start giving credit where it is due alongside those who have already been recognized, while also pointing out how women's subjugation and disempowerment have been obscured by their male contemporaries and by history. By doing so, women's rebellion-and 
the rebellions of others likewise stifled-may be recuperated and rewritten back into national narratives.

\section{The Modern/Colonial Gender System and Nationalist Projects}

To more deeply analyze women's rebellion-and to more comprehensively examine the "revolting" nature of the women who broke with nineteenth-century notions of femininity-María Lugones' framework of the modern/colonial gender system provides valuable insight into analyzing colonial gendered contexts. Her concept draws on important work done on the coloniality of power, specifically as used by Anibal Quijano, and provides a crucial expansion of it by linking it to the concept of intersectionality, specifically as examined by Julie Greenberg, Oyéronké Oyewùmí, Paula Gunn Allen, and others. Lugones is interested in the intersection of race, class, gender, and sexuality in a way that allows her "to understand the indifference that men, but, more importantly to our struggles, men who have been racialized as inferior, exhibit to the systematic violences inflicted upon women of color" (188). For her, this indifference is insidious because of the immense barriers that it places in the path of these women as they struggle for freedom, integrity, and well-being. I am likewise interested in these intersections as I question why these men, particularly José Martí and José Rizal, minimized women's participation in the nation-building project and their contemporary appeal as "national heroes," despite their stifling of women's agency.

To begin, Anibal Quijano shows how the global capitalist system of power relies on the two axes that he calls the "coloniality of power" and "modernity." In studying the relationship between colonialism, Eurocentrism, and social classification in creating hierarchies, he contends that two historical processes have shaped the coloniality of power: (1) the codification of differences between the colonizer and the colonized and (2) the constitution of new structures of control over labor, resources, and its products (182). So, for Quijano, coloniality establishes the classification of the planet's population in terms of the idea of race. Moreover, societiesand, in this case, nation-states-are power structures articulated by "(1) the 
disputes over the control of labor and its resources and products; (2) sex and its resources and products; (3) authority and its specific violence; (4) intersubjectivity and knowledge" (205). He understands modernity as the melding of the experiences of coloniality with the necessities of capitalism. Europe's strength, according to Quijano, was its ability to spread and establish its power through the colonization of the culture of the colonized. The coloniality of power, in other words, is the project of creating the colonized in the image of the (European) colonizer.

María Lugones complicates his framework and argues that, in addition to race, gender itself was "a violent [colonial] introduction consistently and contemporarily used to destroy peoples, cosmologies, and communities as the building ground of the 'civilized' West" (186). Put differently, colonialism imposed a new gender system on the colonized that erased pre-existing conceptualizations of gender, thereby significantly redefining different arrangements for colonized males and females than for white, usually bourgeois colonizers. For Lugones, Julie Greenberg's work discusses the ways in which legal institutions have had the power to assign individual to specific racial or sexual categories. These institutions have tended to presume sex as binary via the normalization of sexual dimorphism, that binary sex is "determinable by an analysis of biological factors" (which fails to recognize biological intersexuals), and by revealing that biological sex is socially constructed (qtd. in Lugones 194).

Related to this, Oyéronké Oyewùmí's study of gender in pre-colonial Yoruba society, for Lugones, shows that gender was not an organizing principle prior to colonization by the West and that gender became important because Yoruba life "has been translated into English to fit the Western pattern of body-reasoning” (qtd. in Lugones 196). Oyewùmí's work shows an understanding of gender as a "tool of domination that designates two binarily opposed and hierarchical social categories," shedding light on the economic, political, and cognitive subordination of women (Lugones 197). Meanwhile, Paula Gunn Allen characterizes many Native American tribes as gynecratic, emphasizing the centrality of the spiritual in Native life and thus a different form of intersubjectivity: "Replacing this gynecratic spiritual 
plurality with one supreme male being as Christianity did, was crucial in subduing the tribes" (Lugones 199). Therefore, the subjugation of Native females was tied to the domination and transformation of tribal life. For Lugones' framework, Allen illustrates how the production of knowledge is gendered and that the heterosexuality characteristic of the modern/colonial gender system is mythically constructed. Allen also discusses how the European colonizer "constructed an inside force as colonized men were co-opted into patriarchal roles" (Lugones 200).

It is vital, then, to understand the place of gender in precolonial societies to recognize the scope and nature of the changes in the social structure imposed by this system, as well as its role in disintegrating societies. In Cuba, for instance, the pre-colonial Taino society was based on a matrilineal system. Historical evidence suggests that the Tainos had nonspecialized gender roles in most activities, participating nonexclusively in political leadership, war, and the production of food and craft, among other activities (Deagan 600). Taino women, then, were able to wield political power at all levels, as well as accumulate wealth. However, shortly after Christopher Columbus' arrival in Hispaniola, the Spanish subjugated the island and formally imposed the encomienda system in 1503, under which the Tainos were required to exchange their labor for instruction in Catholicism and "civilization." By the middle of the sixteenth century, the Taino population was decimated to the point of being unidentifiable as a social entity (Deagan 602).

Similar to Cuba, Filipino writers have directly attributed women's inferior status to the arrival of the Spaniards, pointing out that women in pre-Hispanic Philippines enjoyed an equal or elevated status as men in society, conducted their own businesses, owned property, and had the right to divorce. ${ }^{5}$ As in Cuba, societal changes were due in no small part to the powerful, pervasive position and influence of the Catholic Church. When the Legazpi expedition arrived on the islands in 1565, missionaries began to establish their presence. Their primary objective was to spread Christianity among the natives. Wielding the tenets of the Catholic Church, the frailocracy, or the government rule by the friars, amassed substantial power. In conjunction with the imperial colonizing project, the frailocracy imple- 
mented a patriarchy-based gender system that violently changed and diminished the status of colonized women. Women were no longer allowed to hold high offices, own their own property, or engage in business without their husband's consent; divorce became definitively forbidden and continues to be so today.

Recalling Greenberg's study: the institution of the Catholic Church was instrumental in assigning racial and gender categories in both archipelagos. By the nineteenth century, the gender system established "proper" Cuban women as uneducated, submissive, and dependent upon men, per social customs prescribed by the Catholic Church. If a woman received any education at all, it was in Catholicism which enhanced their purity and virtues as mothers. Their place in society was to bear children and do domestic work. For women outside of the privileged classes-namely, poor and/or black or mulatta-the subordination was amplified. Social customs viewed poor women of any race as inferior, destined to be unwed mothers and workers outside of the home. Similarly, in the Philippines after the sixteenth century, convents and their associated boarding schools played a substantial role in molding Filipino girls and women into this same ideal, so instruction generally consisted of the Christian doctrine, reading, writing, needlework, and occasionally arithmetic. Teachers also took care to emphasize and enforce rules of courtesy and piety, particularly in relation to the classroom, the presence of one's elders, and in the church. Evoking Oyewùmí and Allen, the implemented gender system was used as a tool for domination; we also perceive the massive scope of how it changed each society. We can also see how this gender system was comprehensively informed through the coloniality of power.

This dual framework joining intersectionality with the coloniality of power more deeply contemplates gender and its tangled relationship with race. Quijano's understanding of sex and gender, according to Lugones, is defined by patriarchal and heterosexual understandings of "sexual access" as he

appears to take for granted that the dispute over control of sex is a dispute among men, about men's control of resources which are thought to be female. Men do not seem understood as the resources in sexual encoun- 
ters. Women are not thought to be disputing for control over sexual access (Lugones 194).

Therefore, she believes, his reliance on a paradoxically European understanding of gender is restrictive (194). Where Quijano introduces the idea of race as an organizing principle of colonialism, Greenberg, Oyewùmí, Allen, and others remind us how coloniality pervades all aspects of social existence, including and especially gender, giving rise to new social and geo-cultural identities. From here, Lugones issues a critique of white feminism within the modern/colonial gender system framework. In so doing, she not only calls attention to the intricacies of racial formation, but also to the need to historicize gender formation because, "without this history, we keep on centering our analysis on the patriarchy" (187).

\section{Martí and the Modernista Female Ideal}

By the early nineteenth century, revolutions against Spain in the Americas resulted in the creation of several independent countries. With these changes came considerable political instability as these young nations navigated their new, independent standings. Amidst this turbulence emerged the Latin American modernista movement, which sought to renew a poetic language, filled with elegant, exotic, luxurious, and mythological imagery. It aimed to achieve an ideal of beauty, creating arte por el arte, or art for art's sake, in its pursuit of perfection. Within this context, modernista authors-specifically, male ones-constructed and represented the "ideal" woman for midto late-nineteenth century society. The literary production of José Martí, widely considered the Cuban national hero, makes sense as a point of departure. Throughout his career, he wrote extensively for a variety of newspapers, composed poetry, and published essays, often reflecting his views on social and political matters, including the subject of Cuban independence. To this day, the image of women's heroism, dedication, sacrifice, and allegiance to la patria permeates Cuban nationalist folklore; we can trace his chronicles to see how Cuban ideals of women's roles evolved with nationalist goals and sentiments. 
It is no surprise, then, that attitudes reflecting colonial gender arrangements regarding "proper" behavior during the nineteenth-century, in tandem with the literary context of the modernista movement, surface in José Martís work. In a book review evaluating a collection of American female poetry published on August 28, 1875, ${ }^{6}$ José Martí critiques the text for its heavy inclusion of Gertrudis Gómez de Avellaneda's poems due to "la grandeza y la severidad" ["greatness and severity"] in what should be "poesía femenil" ["feminine poetry"] (310). Avellaneda, perhaps the most well-known female poet of the early nineteenth-century, wrote broadly on slavery, independence, and women's intellectual capacities. Many of her works expressed rebellion against a male-dominated society and questioned women's inferior standing, often comparing women's social position to slavery. Her most famous work, the antislavery novel Sab (1841) which tells the story of an enslaved mulatto who is in love with the white daughter of his master, critiques the institution of marriage by drawing on these parallels.

As the daughter of a Spanish father and a criolla mother, Avellaneda's social status as a white, Cuban woman of privilege provided access to intellectual circles in Spain and allowed her to boldly express herself with fewer repercussions. Yet, despite her love for Cuba and championing causes that Martí would likewise later espouse, she did not embody the characteristics of the "proper" Cuban woman. In Martí's book review, he laments the focus on Avellaneda's work and the corresponding lack of emphasis on the poetry of Luisa Pérez, a contemporary who wrote about her grief after the loss of her husband. He describes Pérez as a

pura criatura, a toda pena sensible y habituada a toda delicadeza y generosidad. Cubre el pelo negro en ondas sus abiertas sienes; hay en sus ojos grandes una inagotable fuerza de pasión delicada y de ternura; pudor perpetuo vela sus facciones puras y gallardas, y para sí hubiera querido Rafael el óvalo que encierra aquella cara noble, serena y distinguida.

[pure child, sensitive to all pain and accustomed to all delicacy and generosity. Her black hair falls in waves around her temples; in her profound eyes is a limitless force of delicate passion and tenderness; perpetual modesty veils her pure and elegant features, and for himself, Rafael would have 
wanted the oval that encloses that noble, serene and distinguished face.]

("Tres libros" 310, translation mine)

When considering that the modernista movement strove for perfection vis-à-vis the pursuit of a beautiful ideal, Martí's description of Pérez speaks volumes. He highlights her corporeal attributes and how they convey innocence, fragility, and virtuous propensities, equating her poetry-and her physical beauty-to this exquisite ideal. Likewise, these characteristics also exemplify the qualities of the "ideal woman" of the time, illuminating Martís adherence to this colonial gender system. On the other hand, in evaluating Avellaneda's poetry, Martí emphasizes its masculine qualities: "Hay un hombre altivo, a las veces fiero, en la poesía de la Avellaneda" ["There is an arrogant man, fierce at times, in the poetry of Avellaneda"] ("Tres libros" 311, translation mine). Therefore, in his evaluation of who is "la mejor poetisa americana" ("the best American poetess"), Martí concludes without hesitation that it is Pérez, citing that

No hay mujer en Gertrudis Gómez de Avellaneda: todo anunciaba en ella un ánimo potente y varonil; era su cuerpo alto y robusto, como su poesía ruda y enérgica; no tuvieron las ternuras miradas para sus ojos, llenos siempre de extraño fulgor $y$ de dominio: era algo asi como una nube amenazante.

[There is no woman in Gertrudis Gómez de Avellaneda: everything in her revealed a potent and manly spirit; her body tall and robust, as her poetry was rough and energetic; tender glances her eyes did not have, always filled with a strange brilliance and power: it was something like a threatening cloud.] (“Tres libros" 311, translation mine)

Evidently, Martí finds Avellaneda's rebellion against socially prescribed femininity revolting and, in fact, threatening to the white bourgeois patriarchal system. She does not embody the ideals of feminine beauty of the time; rather, she actively revolts against it. In contrast, Pérez embodies purity, delicateness, and subordination to her husband.

According to Lugones' framework, these traits are crucial for characterizing white bourgeois females who are meant to reproduce the class, 
colonial, and racial standing of white bourgeois men (206). In pitting Pérez and Avellaneda against one another through poetry, Martí puts forward two views. First, he confirms his adherence to a heterosexualist hierarchy, not only in his unquestioned acceptance of biological dimorphism, but also in his support of defined gender roles that reproduce patriarchal control. Second, he asserts knowledge production as belonging to the masculine sphere and, conversely, women's exclusion from this domain, evidenced by her supposed physical and intellectual weakness. It is worth noting that he begins his description of Pérez with her physical attributes; her poetry is secondary. Meanwhile, Avellaneda's lack of conveyed weakness revolts against this worldview.

As Cuba began to near the 1896 War of Independence from Spain, women became more involved in anti-colonial movements; therefore, Martí needed to revise his literary portrayals of women. The rise of women's clubs in Cuba and in the United States' Cuban émigré community and newspapers reporting on the female mambisa presence among the insurgent fighters, evidently and effectively contributed to the Cuban cause. As Martís commitment to Cuba's liberation grew, women's involvement became an asset. Lynn Stoner points out that in the years leading up to and during independence campaigns, Cuban leaders and intellectuals tried to unify rebels around symbols of patriotism to establish a nationalist spirit. The mambisa, according to Stoner, represented a perfect citizen to instruct the nation in new values, such as loyalty and sacrifice: "Woman warriors a la cubana could fight as men, nurture as women, and stand beside their men in refusing to surrender to the Spanish Crown, all while asking little for themselves" ("Militant heroines" 73). Note that this continues to reflect the societal expectations that women-despite their ability to fight-were to remain subordinate to the "men's war."

Almost twenty years after his writings on Avellaneda, Martí's chronicles leading up to the War of Independence co-opt the image of the mambisa warrior to serve nationalist ends. In two chronicles written for the paper Patria-"Mariana Maceo" in 1893 and "La madre de los Maceo" in 1894Martí memorializes Mariana Grajales Coello as the legendary model of the 
patriotic mother, due to her willingness to sacrifice not only her husband, but her ten sons for Cuba. One of these sons was the famed General Antonio Maceo, earning her the epithet "Mother of the Cuban Independence." In these chronicles, Martí relates two legends surrounding Grajales to emphasize her Spartan-esque aura; these are the images of women's patriotic heroism that remain today. In the first, he tells of how she taught her sons how to use the machete as a weapon and, as a dedicated, patriotic mother, instilled in them dreams of an independent Cuba. Reporting on her death in the paper Patria, Martí depicts her

Con su pañuelo de anciana a la cabeza, con los ojos de madre amorosa para el cubano desconocido, con fuego inextinguible, en la mirada y en el rostro todo, cuando se hablaba de las glorias de ayer, y de las esperanzas de hoy, vio Patria, hace poco tiempo, a la mujer de ochenta y cinco años que su pueblo entero, de ricos $y$ de pobres, de arrogantes $y$ de humildes, de hijos de amo $y$ de hijos de siervo, ha seguido a la tumba, a la tumba de tierra extraña. Murió en Jamaica el 27 de noviembre, Mariana Maceo.

[With her old handkerchief on her head, with a loving mother's eyes for the unknown Cuban, with inextinguishable fire, in her gaze and on her face, when talking about yesterday's glories, and the hopes of today, Patria saw, a short time ago, a woman of eighty-five that her entire town, rich and poor, arrogant and humble, children of masters and children of servants, has followed to the grave, to the grave of a strange land. In Jamaica on November 27 died Mariana Maceo.] ("Mariana Maceo” 25, translation mine)

As a mixed-race woman-Spanish and African-Grajales symbolized Martís ideal of Cuba as a nation of racial harmony. She was a woman willing to sacrifice everything, including her family, for her nation. However, he highlights her role as a loving mother for all Cubans-the stranger, the rich, poor, arrogant, humble, and children of both masters and slaves.

Martí then details Grajales' patriotic virtues and sacrifice for Cuba, focusing on her ability to inspire the troops on the battlefield and on her selflessness in sending her own (male) family members to fight. In the second chronicle, he recounts a well-known story about the time when 
Grajales sent her youngest son into battle. Upon receiving news of the death of her eldest-and with all her other sons on the battlefield-she turned to the youngest and said, " $¥ Y$ tú, empinate, porque ya es hora de que te vayas al campamento!" ["And you, rise up, for now is the time for you to go to the battlefield!"] ("La madre” 27). While Martí allows her more of a "masculine” role than for Avellaneda in sanctioning her patriotic fervor, he highlights Grajales' ability to produce Cuban fighters and limits her knowledge production-her patriotism-to the domestic sphere. According to the gender system constructed via the Catholic Church, this is the space where a woman may have authority. Echoing his descriptions of Luisa Pérez, Martí focuses on her virtue and purity by employing religious imagery that depicts her as a sort of Virgin Mary-simple, humble, and anointed. He writes:

¿Qué había en esa mujer, qué epopeya y misterio había en esa humilde mujer, qué santidad y unción hubo en su seno de madre, qué decoro y grandes hubo en su sencilla vida, que cuando se escribe de ella es como de la raíz del alma, con suavidad de hijo, y como de entrañable afecto? Así queda en la historia, sonriendo al acabar la vida, rodeada de los varones que pelearon por su país, criando a sus nietos para que pelearan.

[What was in that woman, what epic and mystery was in that humble woman, what sanctity and anointment in her mother's bosom, what decorum and greatness in her simple life, that when one writes of her it is like the soul's origin, with a child's gentleness, and as endearing affection? As is the story, smiling at the end of her life, surrounded by the men who fought for their country, raising their grandchildren to fight.] " $L a$ madre" 26 , translation mine)

Surrounded by the men who fought for the country and raised grandsons who would fight, her death reflects Martís sustained assumption that fighting for one's country is men's work.

Finally, when Martí mentions her presence on the battlefield, he does not depict her fighting even though there has been evidence of her military action (Stoner 26). Instead, in his account, she is limited to inspiring the fighters, tending to wounds, and providing moral support to the wounded. Even this form of participation on the battlefield in the Ten Years' War is 
secondary to her role as mother. This role punctuates Martí's last line of the piece, stating "Patria en la corona que deja en la tumba de Mariana Maceo, pone una palabra: - ¡Madre!" ["Patria on the wreath it leaves on Mariana Maceo's tomb, places one word - Mother!”] (26). By limiting her participation as primarily supportive and as a mother who sacrifices, Martí genders war and citizenship as spheres assigned to men and restricts women's participation in constructing national discourse.

\section{Militant Mambisas}

In light of Lugones' model, we infer from Martís stance that it is not a woman's place to think about the nation, let alone politics; rather, that their minds should instead be focused on nature, beauty, and emotions. In accordance with the gender system, he takes for granted that national sentiments and political messages are reserved for men's expression, whereas women's expression should simply support men's messages, focus on family and motherhood, and/or be nonexistent. Listening beneath the flow of male national literary canon reveals that Cuban women did, in fact, conceptualize citizenship and nation, contrary to history's attempted minimization of their efforts. Furthermore, it uncovers the fact that women believed in an inclusive independence that looked beyond their nationalist, discursive roles as mother.

Looking beyond Martí's critiques, Gertrudis Gómez de Avellaneda's poetry evidences the emergence of a distinctly female Cuban identity and, perhaps, a proto-nationalist sentiment. Her well-known poems "Al partir," written in 1836 as she left for Spain, and "La vuelta a la Patria," written in 1860 after her return to Cuba the year prior, exemplify her love of the island. However, a distinctly Cuban identity emerges in her poem "A las cubanas" (1860). Published in the women's journal Album Cubano de lo Bueno y lo Bello (1859-64) that she edited, she begins:

Respiro entre vosotras joh hermanas mías! Breathe among yourselves, o my sisters!

Pasados de la ausencia los largos dias, $Y$ al blando aliento
The long days of absence past, And on the soft breath 
De vuestro amor el alma revivir siento. Of your love I feel my soul rekindle.

$$
\text { (1-4, translation mine) }
$$

In these lines, Avellaneda refers to her "hermanas," situating herself within a female Cuban community that is mutually supportive and uplifting of one another. Her specificity in speaking directly to women-"vosotras," "hermanas mias"-pointedly excludes the men who are the "default" in the modern/colonial gender system and who are indifferent to the women's plight. About halfway through the poem, Avellaneda encourages the use of poetry and the arts to empower Cuban women to become united, express their love of country, and lift up their voices:

Quizás en este ambiente de poesía Para cantaros cobre nueva armonía, $Y$ al sol de Cuba

-Vuestro amor bendiciendo - su canto suba.
Perhaps for you in this poetic sphere Singing takes on a new harmony, And to Cuba's sun

-Your love blessing it - your song rises.

(29-32, translation mine)

By encouraging women to express themselves through poetry, she begins to break women out of the restrictions of only reading and reciting Catholic catechism. Instead, their song might rise up to the Cuban sun, blessed by their love. She also implies that women do, indeed, have the voice to express themselves in a different sphere than had previously been open to them. In the penultimate verse, Avellaneda proclaims:

Si; porque en esta patria de la hermosura Yes, because in this country of beauty Se aspiran en los vientos gloria y ventura, one inhales glory and fortune in winds, $Y$ hay en sus sones And in its sounds De amor y de entusiasmo palpitaciones. Of love and dedication are palpitations.

Avellaneda inserts her voice into the male-dominated, nationalist, poetic corpus, making a point to draw attention to women's patriotism. Because this is a journal devoted to women, these stanzas specifically show how 
Avellaneda not only saw herself as part of a distinctly Cuban sisterhood, but also that women were already viewing themselves as outside of the assumed colonialist sexual dimorphism. Furthermore, they were Cubans, dedicated to a Cuban nation.

Women continued to develop this civic identity in the decades leading up to the War of Independence. When the Ten Years' War began nearly a decade later, it is true that women generally did not enter the struggle as individuals fighting for women's rights; rather, most began as wives, daughters, sisters, and mothers who joined the efforts with the men. Still, as noted in the beginning of this article, Ana Betancourt de Mora raised awareness of women's contributions to independence and began to draw attention not only to fighting colonialism, but also to coloniality (read: patriarchy). The rebels at this Congress were in the process of writing the Bases de la revolución to outline their governing body and its principles. Attending in place of her ailing husband, Betancourt urged the group to consider the problem of women's subjugation:

The Cuban woman, from the dark and tranquil corner of her home, has waited patiently and with resignation for this sublime hour in which a just revolution will break her yoke, will untie her wings. Everyone has been enslaved in Cuba: families, people of color, and women. You will fight to the death if necessary to destroy racial slavery. Racial slavery no longer exists. You have emancipated men of servitude. When the moment arrives to liberate women, Cuban men, who were subjugated in familial and racial slavery, will also dedicate their generous souls to women's rights. For women, who today and in wartime are their sisters of charity even while they are denied their rights, will tomorrow be men's exemplary companions. (qtd. in Stoner, From the House 22)

Like Avellaneda in her book Sab, Betancourt draws parallels between racial slavery and women's inferior status in society, linking them to the colonial condition. Her speech, rote with images of enslaved bodies, seeks to dismantle colonialism's legacies of both racial and gendered systems of oppression. Because women were active participants in working toward a free Cuba-in contrast to women's "supportive role" put forth by Martí-Betancourt sees 
women as essential partners in the process of nation-building. Nevertheless, despite her passionate speech, and despite the representatives' recognition and praise for women's heroism, the assembly did not consider granting women's rights: "From the representatives' perspective," observes Stoner, "women were adequately represented through the legal power of men" (From the House 23).

By 1895 , at the start of the War of Independence, mambisas had not only fought as patriotic mothers, wives, sisters, and daughters who supported their families' causes, but also assumed new roles as protagonists independently leading the fight. Women of all classes and races enlisted in patriotic clubs, both on the island and in expatriate communities. Teresa PradosTorreira notes that women's participation in the War of Independence was "more than embroidering flags and dreaming of revenge. It involved a wide array of clandestine activities that placed them at the political epicenter of the insurgency" (103). Accordingly, mambisas were not shy in demanding the full incorporation of women as citizens in their visions of a free Cuba. For example, in 1891, Edelmira Guerra demanded access to public education, women's right to vote, the right to divorce, and the right to work-all roles outside of motherhood (Prado-Torreira 131-132). In 1895, Aurelia Castillo likewise imagined the new Cuban woman as citizen:

A great revolution, among various others, is coming about. Women are demanding their rights. They have been the last slaves of this civilized world. No, something even worse than that: they have been, until now, the laughable sovereigns of a society that is gallant and brutal at the same time. (qtd. in Prados-Torreira 132-133)

Again, images of slavery emerge in Castillo's writing. Her reference to a "gallant and brutal" society suggests her recognition of the inherent coloniality that co-opted men into a heterosexualist system that violently maintained women as inferior. During and after revolution, women fought in part because they understood that independence could simply mean a reorganization of the colonial hierarchy that continued to subjugate women. In 
the revolution's attempt to destabilize the use of race as the default mode of classification, they saw the danger of simply changing the focus onto gender.

\section{Rizal's Recommendations}

The entrenchment of these oppressive colonial gender arrangements in Cuba and the ways that women attempted to break out of these arrangements provide a unique lens with which we might evaluate nineteenth century Philippine society. In 1863, the Spanish monarchy enacted an Education Decree that mandated free primary education in the colonies along with compulsory education in the Spanish language. However, this was not the first decree of its kind; several had been issued in the centuries prior but had been disregarded. Encarnación Alzona in The Filipino Woman (1934) remarks that, in women's education, “the Spanish language was also taught indifferently, for the aim of these institutions was not to turn out learned women, but devout, chaste, modest, and diligent women who would become good mothers" (28). Thinking back to the modern/colonial gender system framework, these legal institutions-especially the frailocracy in the Philippines-used gender categories as a tool to reproduce coloniality. We remember that these characteristics-sexual purity and passivity-are crucial in females who reproduce the standing of bourgeois, white men (Lugones 206). Lugones elaborates that

equally important is the banning of white bourgeois women from the sphere of collective authority, from the production of knowledge, from most control over the means of production. Weakness of mind and body are important in the reduction and seclusion of white bourgeois women from most domains of life, most areas of human existence. (206)

When we consider the collusion of colonized men in consenting to this patriarchal hierarchy, it is no surprise that, by the nineteenth century, José Rizal's figure of María Clara embodied the "ideal woman" in the Philippines-that is, overly pious, submissive, and obedient, and whose virginity and virtue must be protected. Evoking Quijano, the coloniality of power draws its strength 
from the colonization of the culture of the colonized; this is no different in the enactment of the coloniality of gender.

Without a doubt, Rizal is the Philippines' national hero. A polymath, intellectual, ophthalmologist, and prolific writer, he is the best known of the ilustrados, a group of young Filipino intellectuals who worked for reform and representation in the Spanish courts during the latter part of the nineteenth century. Yet, despite his liberal education in Europe, Rizal's description of a weak, submissive, and delicate María Clara as the ideal love interest in the Noli-echoing Martí's description of Luisa Pérez-shows that even he could not escape the Catholic Church's ability to naturalize heterosexualist beliefs about gender in the Philippines. Interestingly, in stark contrast to the mambisa warrior of Cuba, María Clara represents the Philippine ideal woman that remains the model to this day. The historical treatment of the young women of Malolos, referenced at the beginning of this article, speaks to colonialist fidelity. The women's defiant act of petitioning for a night school in 1888 canonized them in Filipino history when women's education was minimal and anti-clerical sentiment in the archipelago ran high.

Nicanor Tiongson, in his extensive book about these women, admits that much of the malolensas' historical value-and why they do have a place in the historical memory of the Philippines - has come from male exaltation of their rebellion: Graciano Lopez-Jaena, for example, wrote about the malolensas [the women of Malolos] for the first issue of La Solidaridad, the ilustrados' newspaper; Fernando Canon, a lesser-known propagandista, composed a sonnet in their honor (also for La Solidaridad); and of course, Rizal, the most famous Filipino of them all, penned a letter in Tagalog to them, lavishing praises for their act. As one of the few documented acts of women's rebellion of the time, a closer study will illuminate how Rizal rewrote the women's call for education to simultaneously serve the needs for fomenting nationalist fervor, maintain the ideal María Clara narrative, and minimize women's participation in the nation-building discourse. Analyzing the discourse put forth by the ilustrados surrounding the malolensas' letter lets us see how they co-opted the women's act to further entrench the colonialist gender system. 
To provide some context: Marcelo H. del Pilar had written a message to Rizal letting him know about the women's petition to Governor General Weyler. Del Pilar tells Rizal that they are "de la clase escogida del pueblo, respetadas por la honrosa reputación e hijas de maginoos" ["of the chosen class of the town, respected for their honorable reputation and daughters of manginoos"] (120, translation mine). He requests that Rizal write a letter in Tagalog to the women because it would promote the ilustrados' campaigns for reform:

Si pudiese $V$. dirigirles una carta en tagalo, sería un auxilio más para nuestros campeones de alk y de Manila. Debido a la propaganda de esas muchachas que predican con la palabra y con el ejemplo, ya se va popularizando en provincias la idea de ser deshonrosa para el hombre y para la mujer la adhesión al fraile y esto está produciendo grandísimos efectos.

[If you could write them a letter in Tagalog, it would be more support for our champions there and in Manila. Due to the propaganda of these women that preach by word and by example, the idea of supporting the friar as disgraceful is becoming popular in the provinces for both men and women and this is producing great effects.] (Del Pilar 120, translation mine)

Del Pilar highlights the women's social status and respectability to give authority to their action, suggesting that, had they been of a different class or of ill repute, their work would not have been acceptable. Furthermore, he spotlights their demands mainly to draw attention to the anti-friar movement. One might infer that he likely did not see a role for women in the movement other than promoting the ilustrados' goals.

Rizal's letter to the young women of Malolos reflects del Pilar's attitude, and the greater part of the message is dedicated to expounding on a woman's role in society. In Christine Doran's analysis of women's involvement in nationalist movements and revolutions, she traces common themes in their historical representation. Among them is the depiction of women in (usually male-generated) nationalist myths within four main archetypal roles: "as mother, as traitor, as sex object, and as rape victim" ("Women" 245). Interestingly, Rizal's letter directed to the women references all four of 
these archetypes - here, I'll focus on his extensive description of the mother. The letter begins with Rizal (a bit patronizingly) admitting that his initial impressions about women were rather bleak, stating that few had met his "ideal" until he heard the news of what happened in Malolos. He admits his error and praises the women:

Now that you have responded to our first appeal in the interest of the welfare of the people; now that you have set an example to those who, like you, long to have their eyes opened and be delivered from servitude, new hopes are awakened in us and we now even dare to face adversity, because we have you for our allies and are confident of victory ("To My Countrywomen" 4).

Similar to Martí, Rizal highlights the women's ability to awaken hope and inspire the men. Meanwhile, his assumption that women previously had not thought about fighting for the country's welfare-and that only now, they have "responded" to the men's appeal-suggests that he had not considered women to be possible participants in their national project.

In the next part of the letter, Rizal develops a defense for one's ability to think for oneself, especially when it comes to religiosity. He praises the women for discerning that the "will of God is different from that of the priest" and that religiousness comes from "a spotless conduct, firm intention, and upright judgment" ("To My Countrywomen” 4). Women who blindly follow the church without thought, Rizal reasons, only produce children who are slaves; therefore, he advocates for greater education for girls and women. Like Martí, Rizal rationalizes women's participation in the educational sphere-one controlled by men-by emphasizing that they would then raise a generation of educated, independent sons who would work to advance Filipino society: "Let us be reasonable and open our eyes, especially you women, because you are the first to influence the consciousness of man" (“To My Countrywomen” 10).

In contrast to Martí, however, Rizal seems to struggle more with looking to Europe and the United States as a model to emulate while simultaneously desiring to lift up the nation. On the one hand, he compliments the Filipina for her power and astuteness, harkening back to women's pre-colonial 
status. This, in my view, shows his awareness of the scope of how gender had changed over the centuries. But in the same breath, he paints her in the image of Eve, the woman blamed for the fall of humankind in Christianity, the traitor and the victim:

The power and good judgment of the woman of the Philippines are well known, and it is because of this that she has been hoodwinked, and tied, and rendered pusillanimous; and now her enslavers rest at ease, because so long as they can keep the Filipina mother a slave, so long will they be able to make slaves of her children. ("To My Countrywomen” 11)

Thinking back to Greenberg and Allen, Rizal recognizes that the Filipina was robbed of her pre-colonial power and rights as part of the colonizing project precisely to create a patriarchal society that converted natives into subjects of colonization. Yet, as he casts blame on the colonizers, he looks to them as a model, citing that Asia's backwardness is because "there the women are ignorant, are slaves; while Europe and America are powerful because there the women are free and well educated and endowed with lucid intellect and a strong will" (“To My Countrywomen” 11). Evidently, he has internalized the colonialist view of European superiority.

History has traditionally seen Rizal as one who sought equal representation for Filipinos in the Spanish courts to fight the abuses of the frailocracy; he did not generally advocate independence from Spain until, arguably, near the end of his life. ${ }^{8}$ We might thus infer that he accepted the idea of Spain as superior to the Philippines. We might also view this as evidence of his adherence to a colonialist hierarchy. It would make sense, then, that he wished for the Philippines to emulate the West as a way to elevate its status. In the same lines, the Christian image of Eve, subordinate to her husband, Adam, likely influenced his propagation of the modern/colonial gender system. Notably, the majority of what follows in his letter focuses on the qualities that Filipino mothers should possess, as well as their duties and responsibilities to their husbands and to their children: 
When she is married, she must aid her husband, inspire him with courage, share his perils, refrain from causing him worry and sweeten his moments of affliction, always remembering that there is no grief that a brave heart cannot bear and there is no bitter inheritance than that of infamy and slavery. Open your children's eyes so that they may jealously guard their honor, love their fellow men and their native land, and do their duty. Always impress upon them they must prefer dying with honor to living in dishonor. ("To My Countrywomen" 15).

Again, we see an emphasis on the ways that women must support men's work. Rizal, like his Cuban counterpart, references the image of the Spartan woman as an example to follow. He recounts the myth of the Spartan mother who sends her son to battle with a shield, telling him to return either victorious or dead ("To My Countrywomen" 16). But whereas Martí imbues Grajales' image with the ability to teach practical knowledge (wielding a machete) and patriotic values (sacrifice for one's nation), Rizal focuses solely on the latter. He advises the malolensas to serve as mothers who raise their sons to give their lives for their native lands. Not once does Rizal address alternative ways for women to participate as citizens outside of motherhood. Instead, his evolved version of the patriotic woman is simply an anti-friar María Clara.

\section{Disobedient Dalaga}

It is within this context that we reflect on the impact of the Women of Malolos on Philippine concepts of nation and citizenship. In contrast to the mambisas of Cuba, there is very little as far as a written record of women's perspectives in the time leading up to and during the revolutionary period in the Philippines. As previously mentioned, it was generally known that the friars were opposed to teaching the Spanish language, citing its capacity to endanger Spain's rule over the islands: "To teach the Filipinos Spanish," comments Alzona, "would furnish them with a common language which would in turn facilitate communication, and the spread of subversive ideas and Protestantism" (The Filipino Woman 29). As we know, in reality the frailocracy sabotaged the teaching of Spanish to maintain their own power. This 
power and wealth came from the friars' function as a bridge between the Spanish government, who did not speak the local languages, and the colonized people.

With this in mind, I would like to focus on reading the significance of the women's action. Similar to the mambisas during the Ten Years' War, the malolensas' political involvement was largely facilitated by the commitment of their male relatives to the anti-friar movement during this time period; many of these relatives were working directly with Marcelo $\mathrm{H}$. del Pilar (Tiongson 150). These twenty women were descended from four major mestizo-sangley ${ }^{9}$ clans of Malolos; therefore, they were all relatives by blood or by affinity and belonged to the upper-class which afforded them the opportunity to be politically aware. Most likely, this is also why del Pilar knew about their petition. As previously noted, women's written history in this period is scarce. In fact, Nicanor Tiongson acknowledges that even the very letter that the twenty young women of Malolos wrote, signed, and personally delivered to the Governor-General to open a night school was not actually written by the women themselves nor conceived by them! The credit actually goes to their teacher, Teodoro Sandico, who most likely wanted to protect himself from any potential consequences (Tiongson 171, 184).

In light of these points, it is tempting to think that the women had no agency of their own and only participated in the revolution because Sandico and other reformists had put them up to it. Crucially, Tiongson states that some of the women were not even necessarily supportive of the revolution, nor were anti-friar in their sentiments (although some certainly were). However, support for a friar would have been seen as "revolting"-that is, repulsive-to the ilustrados. This is critical to our understanding of how the modern/colonial gender system was in play. As demonstrated earlier, Rizal and the ilustrados read and used the women's letter as an example of antifriar attitudes; hence, Rizal wrote his letter based on this assumption that the letter was a form of revolt. Historical accounts, therefore, memorialize the women as anti-friar mainly because Rizal himself painted them that way.

This is not to argue for a reading of their lack of agency. I argue that dismissing the women's action simply because they did not personally write 
the letter would be a reductionist view of complex circumstances. Tiongson recognizes that the Women of Malolos who tend to be referenced together as a group (I acknowledge that I do so here for purposes of space) were twenty individuals with individual motivations. To further illustrate these complexities, let us turn to the letter itself, as reproduced in Graciano LópezJaena's article titled "Amor a España" in La Solidaridad. ${ }^{10}$ The letter, followed with the women's names, reads:

His Excellency, the Governor-General of the Philippines,

Your Excellency: We, the undersigned young women and others, do hereby present and petition with due respect to Your Excellency the following: Desirous of knowing the rich Spanish language, stimulated and grateful for your generous spirit in spreading in the country knowledge of the Castilian language and unable to learn it in the schools of Manila-some because of the pressing circumstances in which they find themselves and others because their domestic duties prevent them from studying during the day, we humbly request Your Excellency that we be granted a nights school in the home of an old relative of ours where we shall attend classes accompanied by our mothers to receive lessons in Spanish grammar under a Latin professor who will be paid by us. This professor has given proof of his ability to teach Spanish in a short time. Progress has been observed among his private pupils while on the other hand, without any desire to offend them in their work, we must say that the other teachers of the town have not obtained until now positive results.

It is a favor that we are sure we shall obtain from your well-known generosity. May God keep your precious life many years.

Malolos, December 12, 1888. (La Solidaridad 17)

With the understanding that the letter was written by Sandico, a man informed by the modern/colonial gender system, the format of the petition draws attention to what he imagines is the proper woman's place in society. The excessive expressions of courtesy and humility illustrate the standards for showing appropriate respect to a male, high-ranking Spanish official by mestizo-sangley women, representative of the colonial hier- 
archy. Additionally, the request is for a night school, due to their expected domestic duties. But, ever-watchful in maintaining their virtue, the women will be accompanied by their mothers. However, the letter also notes that the women would like the "professor of Latin" to teach them, as he has achieved "positive results." I read a few insinuations with this request: first, Sandico is doing some self-promotion; second, Sandico/the women allude to the friars' role in impeding the teaching of the language; third, Sandico implicitly offers a first-hand account of the women's own dedication to their learning.

Perhaps this line of reasoning seems tenuous-could we really see women's dedication to their own learning and their own contributions to nationalist efforts in a way that's distinct from Rizal's (and the other ilustrados') interpretation? Here, women's agency and involvement might be best documented in letters exchanged between José Rizal and his (nine!) sisters - many of which, fortunately, have been preserved. The letters primarily reflect daily correspondence and familial updates and thus provide an intimate glimpse into the thoughts and emotions of Rizal and his family. It is also clear that Rizal's fondness for giving advice to women is not limited to his letter to the malolensas. In a particularly gossipy set of exchanges in 1890, his aunt Concha and his sisters Narcisa and Trinidad all inform him that their youngest sister, Soledad ("Choleng"), had married without their parents' consent (Cartas 326, 338, 342). In a letter directed to Soledad, Rizal first praises her for becoming a teacher (Cartas 344). ${ }^{11}$ Yet, the rest of his lengthy letter chastises her for upsetting and potentially dishonoring their family and reminds her of her role: "ser un modelo de virtudes y buenas cualidades," reminding her to think of the family's honor ["be a model of virtue and good qualities"] (Carta 344). Soledad's revolt against the gender system rarely-if ever it would-makes it into the historical narrative.

In any case, the fact that these letters are written in Tagalog, Spanish, and English show his sisters' varying facilities with these languages: one letter from his sister Saturnina dated after February 23, 1892 makes references to speaking a little bit of French; another from his sister Josefa, dated November 21, 1892, playfully chastises him in English for not including her as a recipient in the last batch of letters (Cartas 381, 408). From this corre- 
spondence, we can likewise glean evidence of their civic awareness and their involvement in the national cause. His sister Lucia, for example, in a letter dated May 30, 1890, writes about the abuses of the lay people and the corruption in their town:

Mag babalita acó sa iyo ñg tuncol dito sa ating bayan, segurong mag daramdam ang puso mo, dahil sa cabulagan ñg ating cababayan; ñayon ay purong abuso, caululan at ang despotismo ang nag hahari. Acalain mo nalaang, cung papaano ang mangyayari. [...] ano pa't buloc na buloc ñgayon ang ating bayan. Ang C. (Capitán) ay dalaua ang mucha at segurong prolongado.

[With respect to our town, perhaps your heart grieves in the face of our countryfolk's blindness; now reign abuse, madness, and despotism. You can already imagine what would happen ... In a word, our town is corrupt. The Captain is two-faced and is certain his position will be extended.] (Cartas 333-334; translation mine)

Another letter from his sister Narcisa, dated October 17, 1890, similarly references her attention to political occurrences-and includes four-hundred pesos toward Rizal's cause. In outlining where the money came from, Narcisa writes that the last hundred are a

contribución de las paisanas, entre solteras, casadas y viejas, las cuales desean mandarte más si tuvieran ellas más dinero ahora, pero desgraciadamente en este tiempo anda muy escaso el dinero: veremos en los meses de Enero o Febrero, tal vez podrán mandarte más.

[contribution from the countrywomen, among them single, married, and elderly women, who want to send you more if they had more money now, but unfortunately at this time, money is scarce: we'll see in the months of January and February, perhaps they can send you more.] (Cartas 358; translation mine)

Again, women are contributing to the work of the ilustrados. In the same letter, she warns him that "según nuestra opinión, no conviene que regreses en estos tiempos, porque corres gran peligro, y además de esto, aqui no harás nada, pero alli haces mucho" ["in our opinión, it is not advisable for you to return at this time because you 
run a great risk, and in addition, here you will do nothing, but there, you do a lot"] (Cartas 358, translation mine). Because his sisters are eyewitnesses to the corruption, they are able to provide him with both resources and knowledge for his work. While his sisters were not directly involved with the petition to Governor-General Weyler, their letters shed light on how women did, indeed, think about their ability to contribute to nationalist causes, even if they could only accomplish work through their brother.

Considering that the women faced the two-pronged coloniality of the Spanish empire vis-a-vis the Catholic Church and the patriarchy, we must remember that the women of Malolos likewise took the initiative by demanding education and actively seeking out a teacher. Aside from painting more individualized portraits of the women beyond official, historical accounts in his book, Tiongson also aims to underscore the significance of their gesture by pointing out that the women did not simply exit to the sidelines of history after their controversial petition (184). In fact, he shows how some supported the 1896 revolution against Spain and the war against the United States; how others were involved in the Red Cross and the Asociación Feminista de Filipinas in the early twentieth century; still others concerned themselves with domestic or personal affairs (he carefully notes that this should not be seen as an "easy" or "selfish" decision). I agree with Tiongson that their involvement in fomenting social and political change during and after the revolution indicates their continued desire to become civically involved and to express their desire for a nation and citizenship that included their contributions. The women, as with Rizal's sisters, broke with the narrative that they simply be passive supporters or mothers. So, even if the women of Malolos did not write the letter themselves-and even if they did not conceive of the idea-their actions of secretly pursuing their studies, signing the petition, personally delivering it, and lobbying for the school after its rejection all speak for the women's volition outside the male discourse.

\section{Conclusion: Rewriting Revolting Women}

When the War of 1895 began in Cuba, mambisas of all races fought side-byside with the men and distinguished themselves-and their nation-through 
their efforts. The three-year war, ended by the defeat of Spain by united Cuban and U.S. forces, shaped Cuban ideals and inaugurated a pantheon of heroes as well as martyrs. Yet in the years that followed, lawmakers rarely understood and considered women's rights in reforming laws to conform to patriotic ideals; other dramatic reforms, such as free public education, property rights, and no-fault divorce were passed (Stoner, From the House 34).

In 1896, eight years after the famed petition was presented to GovernorGeneral Weyler, the Philippine Revolution broke out with the revolutionary Katipunan leading the charge. Some of the Women of Malolos went on to join the Katipunan in the fight against oppression, participating actively in the revolution as cooks, couriers, and medical support (Tiongson 191). Katipuneras also served as soldiers, spies, strategists, fundraisers, and guards (Doran, "Literary"189). Yet, little continues to be known about these women, as most studies are collections of short biographies of "outstanding Filipina women" that simply list major events in their lives. ${ }^{12}$ Even the autobiography of Gregoria de Jesús, the president of the women's section of the Katipunan (and wife of Andres Bonifacio, its founder), is found as an appendix in a book about her second husband, Julio Nakpil. ${ }^{13}$

It is undeniable that women thought, wrote, and fought for the revolution in both island nations. This fight comprehensively included independence from both the colonial empire and from patriarchal systems of oppression. When their action is compared to male heroes' literary representation of their involvement as passive mothers-namely, Martí's and Rizal's-the contrast between their revolt and their reframed revolt is glaring. Because of the continued significance of these heroes' discourses in national myths, we must confront and re-evaluate the normalization of these rewritings that limited women's participation to roles as pure, virtuous cheerleaders or mothers (both in reproducing citizens and in reproducing patriotic values); to this day, these narratives continue to confine women. By understanding more about the sources of women's subordination and disempowerment, I hope to help trigger the decolonization of our own ways of thinking, nation and otherwise. 


\section{Notes}

1. "Katipunan" abbreviated the full name Kataas-taasan, Kagalang-galang Katipunan ng mga Anak ng Bayan, or the Highest and Most Honorable Society of the Children of the Nation.

2. See also her book From the House to the Streets: The Cuban Women's Movement for Legal Reform, 1898-1940 (1991).

3. See Doran's "Women, nationalism, and the Philippine Revolution" (1999).

4. Quijano has written extensively and significantly on this topic. Here, my interpretations primarily reference his chapter, "Coloniality of Power, Eurocentrism, and Social Classification" (2008).

5. Here, I have in mind Isabelo de los Reyes' El folk-lore filipino (1889) and Encarnación Alzona's The Filipino Woman (1934).

6. Here, the term "American" refers to the American continents in their entirety, not just to the United States.

7. The maginoos were a nobility social class in pre-Hispanic Philippines.

8. Rizal's El Filibusterismo, the sequel to Noli Me Tangere, is often cited as evidence of him beginning to consider resorting to violence to bring change to the Philippines' status. Interestingly, Rizal also pays homage to the women of Malolos in the book by including a scene of students establishing a Spanish language academy in opposition to the friars.

9. The term "mestizo sangley" refers to the official name applied to a mestizo, or a mixed-race person, who was the offspring of a native mother and a Chinese father, or "sangley."

10. For purposes of space, I put the original Spanish here (the names of the Women of Malolos follow the letter):

Exmo. Sr. Governador general de Filipinas. Excmo. Sr.

Nosotros las jóvenes que suscriben y algunas mas ante $V$. E. con el debido respeto nos presentamos y exponemos: que deseosas de saber el rico idioma español, estimadas y agradecidas por vuestro generosos espíritu de generalizar en el páis la lengua de Castilla; y no pudiendo aprenderla en los colegios de Manila, unas por su escasa fortuna, otras por las apremiantes circunstancias en que se encuentran en sus casas, al hacerlo de dia por estar ocupadas en quehaceres domésticos más perentorios: Con tal propósito-A. V. E. humildemente suplicamos se nos conceda una Escuela nocturna en casa de una vieja pariente nuestra, done acudiremos en compañia de nuestras madres á recibir lecciones de gramática castellana bajo la enseñanza del profesor de latin retribuido por cuenta nuestra, quien en poco tiempo ha dado pruebas de aptitud para la enseñanza del castellano por el adelanto que manifiestan sus discipulos, al paso que los maestros del pueblo, sin tratar por esta de ofenderles en su profesión no han conseguido hasta el presente positivos resultados. 
Es gracia que no dudamos merecer de la reconocida bondad de V. E. cuya importante vida, guarde Dios muchos años.

Malolos, 12 de Diciembre de 1888. (La Solidaridad 16)

11. She had just established a school for at least 25 young girls (Cartas, Notes 62).

12. Guzman, Jovita, et al. Women of Distinction (Biographical Essays on Outstanding Filipino Women of the Past and the Present). Philippines, Bukang Liwayway, 1967.

13. Alzona, Encarnación, editor and translator. Julio Nakpil and the Philippine Revolution With the Autobiography of Gregoria de Jesus. Heirs of Julio Nakpil, 1964. 


\section{Works Cited}

Alzona, Encarnación. The Filipino Woman: Her social, economic, and political status, 1565-1933. University of the Philippines, 1934. hdl.handle.net/2027/ heb.04431.0001.001.

Deagan, Kathleen. "Reconsidering Taino Social Dynamics after Spanish Conquest: Gender and Class in Culture Contact Studies." American Antiquity, vol. 69, no. 4, Oct., 2004, pp. 597-626.

Del Pilar, Marcelo H. “231. Carta de Del Pilar a Rizal”. Epistolario Rizalino, pp. 119-121.

Doran, Christine. "Behind the Lines: Women in the History and Literature of the Philippine Revolution.” Asian Journal of Women's Studies, vol. 7, no. 3, 2001, pp. 7-30.

."Literary Representations of Filipino Women in Revolution." Review of Indonesian and Malaysian Affairs, vol. 32, no. 2, 1998, pp. 189-209.

"Women, nationalism and the Philippine revolution." Nations and Nationalism, vol. 5, no. 2, 1999, pp. 237-258.

Edición digital de las Obras completas de José Martí, 2 Ed. Editorial de Ciencias Sociales del Instituto Cubano del Libro, 1975; Centro de Estudios Martianos y Karisma Digital, 2001. Universidad Interamericana de Puerto Rico, www.metro.inter. edu/cai/jose_marti/Guia.pdf.

Gómez de Avellaneda, Gertrudis. Álbum cubano de lo bueno y lo bello. Revista quincenal de moral, literatura, bellas artes y modas / dedicada al bello sexo y dirigida por Gertrudis G. de Avellaneda. Tomo 1, núm. 1-12, Feb.-Aug. 1860. Biblioteca Virtual Miguel de Cervantes, 2018. www.cervantesvirtual.com/obra/albumcubano-de-lo-bueno-y-lo-bello-revista-quincenal-de-moral-literatura-bellasartes-y-modas-924758.

Kalaw, Teodoro, editor. Epistolario Rizalino, Tomo $2^{\circ}$, 1887-1890. Biblioteca Virtual Miguel de Cervantes, 2015. www.cervantesvirtual.com/nd/ark:/59851/ bmc $2 \mathrm{f} 9 \mathrm{k} 2$.

La Solidaridad, vol. 1, 1889. Translated by Guadalupe Forés-Ganzón, U of the Philippines P, 1967. Hathitrust Digital Library. https://hdl.handle.net/2027/ coo.31924081575114.

López Jaena, Graciano. “Amor a España.” 15 Feb. 1889. La Solidaridad, vol. 1, 1889. Translated by Guadalupe Forés-Ganzón, U of the Philippines P, 1967. Hathitrust Digital Library. hdl.handle.net/2027/coo.31924081575114.

Lugones, María. "Heterosexualism and the Colonial / Modern Gender System." Hypatia, vol. 22, no. 1, Winter 2007, pp. 186-209.

Martí, José. "La madre de los Maceo." Edición digital de las Obras completas de José Martí. Vol. 5: Mujeres. www.metro.inter.edu/cai/jose_marti/Vol05.pdf. 
."Mariana Maceo." Edición digital de las Obras completas de José Martí. Vol. 5:

Mujeres. www.metro.inter.edu/cai/jose_marti/Vol05.pdf.

."Tres libros.-Poetas americanas.-Carolina Freyre.-Luisa Pérez.-La

Avellaneda.-Las mexicanas en el libro.-Tarea aplazada." Edición digital de las

Obras completas de José Martí. Vol. 8: Nuestra América III. www.metro.inter. edu/cai/jose_marti/Vol08.pdf.

Prados-Torreira, Teresa. Mambisas: Rebel Women in Nineteenth-Century Cuba. UP of

Florida, 2005.

Quijano, Aníbal. "Coloniality of Power, Eurocentrism, and Social Classification.”

Coloniality at Large: Latin America and the Postcolonial Debate. Edited by Mabel

Moraña, Enrique Dussel, and Carlos A. Jáuregui. Duke UP, 2008, pp. 181-224.

Rizal, José. “232. De Laong Laan a Del Pilar.” Epistolario Rizalino, pp. 121-122.

."233. Carta de Rizal a las Jóvenes Malolesas.” Epistolario Rizalino, pp. 122-139.

. Cartas entre Rizal y los miembros de su familia: 1887-1896. Segunda parte.

Comisión Nacional del Centenario de Jose' Rizal, 1961. www.cervantesvirtual. com/nd/ark:/59851/bmcmk8d2.

."To My Countrywomen, the Young Women of Malolos.” Translated by

Teodoro Kalaw, R. Martinez \& Sons, 1958.

Stoner, K. Lynn. From the House to the Streets: The Cuban Women's Movement for Legal Reform, 1898-1940. Duke UP, 1991.

."Militant Heroines and the Consecration of the Patriarchal State: The

Glorification of Loyalty, Combat, and National Suicide in the Making of Cuban

National Identity." Cuban Studies, vol. 34, 2003, pp. 71-96.

Tiongson, Nicanor G. The Women of Malolos. Ateneo de Manila UP, 2004. 